\title{
ADOPTION OF INTERNAL WEB TECHNOLOGIES BY OECD TURKISH GOVERNMENT OFFICIALS
}

\author{
İlkay Unay Gailhard \\ Leibniz Institute of Agricultural Development in Transition Economies (IAMO), \\ Germany
}

\begin{abstract}
Use of communication and information channels for the OECD have been increasingly encouraged by new channels such as the OECD's Committee Information Service (OLIS) and Clearspace (CS) web portals. A logit regression model was used to estimate the influence of the government's supply side policy tools and organisational factors on the decision to open OLIS and Clearspace accounts. Additionally, probability analysis conducted to give insights on the usage frequency of information channels. Study used a dataset that includes 126 Turkish top-level country and municipal government officials working on different OECD study topics in 2010. Findings imply that the influence of the explanatory variables tested differ between the two web-portal models. Satisfaction with the timing of information provided by the OECD Permenant Delegation (timing issues in reaching reports) among officials is the only variable that consistently has a positive influence on the adoption of both web-portal applications. The probability analysis show that while duration of employment and degree of expertise increase the probability of use of online information channels, work duration on OECD topics and meeting participation are the variables that decrease the probability of use of face to face communication channels.
\end{abstract}

\section{KEYWORDS}

Information and communication channels, innovation, adoption of internal web technologies, OECD, government officials, Turkey

\section{INTRODUCTION}

Information and its exchange is one determinant for the effectiveness of the work of organisations with the intention of joint problem-solving, carrying out and encouraging specific activities, creating ideas, norms and reducing transaction costs [1]. Generally, efficient and effective coordination of dynamic processes requires the quick transfer of high quantities of information [2].

Public organisations have made considerable managerial efforts to improve internal and external information flow in public administration through the adoption of information technology (IT). Information technology, more specifically the functionality of web technologies in public management has provided many possibilities for improving the efficiency of managerial tools that collect, store, organise and manage a high quantity of data. 
International Journal of Managing Public Sector Information and Communication Technologies (IJMPICT) Vol. 5, No. 4, December 2014

Using internal web technologies (IWT), government officials can transfer funds and data to other government units or exchange information among public administrative professionals at national or international organisations. Government officials following the studies of international organisations can also complete daily tasks more easily, such as accessing document archives, publications and statistics, and responding to committee employees' requests for necessary statements and documents.

The Organisation for Economic Co-operation and Development (OECD), which is the central interest of this paper, has various work drivers that interact via various information and communication channels. Besides the challenge of establishing favourable framing conditions and organisational structures, the value of information transfer and its usage strongly depend on the commitment of the involved parties. These are the organs of the OECD, member states or national government officials, and their willingness to contribute to and invest into the information networks in the form of time or human capital.

At the OECD, decisions concerning the selection of government officials and organisation of their schedules in performing for OECD work are left to the member countries. The selection criteria of relevant government officials that would have an active role in the use of OECD information channels for national policy work has been quite diverse amongst the member states.

The motivation of the article is twofold. First, Turkey, one of the founding OECD countries, is an interesting case for studies on the adoption of innovation that could give more insight into the role of government's supply side policies as an innovation diffuser. In Turkey, selected government officers working on OECD study topics have a high level of dependency on financial flow coming from central government. Second, regarding the literature on international organisations, we observe that particular focus has been given to the political and strategic aspects (e.g., in terms of power constellations and negotiations). However, less attention has been paid to the administrative technical functioning of international organisations that provide services for facilitating information exchange between member states and governmental officers. Based on the study of Osborne and Brown [3] and Rogers [4], we used the definition of innovation in the public sector as "The introduction of new elements into a public service - in the form of new knowledge, a new organization, and/or new management or processual skills, which represents discontinuity with the past". Given definition highlights that innovation is not only about adoption of a new idea, but used the new ideas in practical level.

This research aims to contribute to the studies on the role of government and organisational factors in the adoption of IWT by government officers. We used a dataset collected in 2010 that includes 126 Turkish top-level country and municipal government officials working on different OECD study topics. To guide the analysis, an analytical framework has been developed to address the influence of government supply side policy tools (e.g., provision of experienced or specialized officials) and organisational factors (e.g., interpersonal communication in the organisation and government official perceptions on bureaucratization). Based on innovation adoption theory, this study has an objective to give further insights into the question of what determines the adoption of IWT applications among government officers. This paper focuses on the adoption of two web-portal applications that are provided by OECD work drivers: OECD's Committee Information Service (OLIS) and Clearspace. Officers' adoption decision framed as a dichotomous problem and logit regression model is applied as an innovation adoption model. 
The paper is structured into six sections. In the following section, we draw background information on the OECD work drivers and use of IWT by Turkish government officials. In the third section detailed information on the studied data set has been provided with the summary statistics for the variables used. The fourth section presents the methodological aspects of the analysis. Section five presents the results of logit regression analysis. Finally, conclusions are derived and discussed in the last section.

\section{BACKGROUND}

\subsection{OECD Information and Communication Channels}

In this paper Turkish government officers that are following OECD study topics are the main focus of the investigation. Turkey along with the other 19 founder countries signed the convention founding the OECD at 1960. On the national level, OECD projects are coordinated by a number of national coordination units and relevant authorities under the direction of the Prime Ministry of Turkey since 2008. The Ministry of Economy has been assigned as the national coordination unit for the several national OECD Committees. To provide systemic coordination between authorized governmental bodies and to undertake the OECD's work, annual coordination meetings are held in Ankara and Paris. Table 1 summarizes four OECD work drivers by information and communication channels potentially used by Turkish government officials.

Table 1. Information and communication channels potentially used by OECD Turkish government officials

\section{Studied OECD Work Drivers}

\begin{tabular}{cccc}
\hline $\begin{array}{c}\text { i. National } \\
\text { Coordination } \\
\text { Units }\end{array}$ & $\begin{array}{c}\text { ii. The OECD } \\
\text { Turkish } \\
\text { Permanent } \\
\text { Delegation }\end{array}$ & $\begin{array}{c}\text { iii. OECD } \\
\text { Committees }\end{array}$ & $\begin{array}{c}\text { iv. The OECD } \\
\text { Secretariat }\end{array}$ \\
\hline $\begin{array}{c}\text { Face to face } \\
\text { (during national }\end{array}$ & Face to face & Clearspace web-portal & OLIS web-portal \\
and institute-level & E-mail & Clearspace e-mail alert & OLIS e-mail alert \\
meetings) & & system & system \\
E-mail & & & \\
Mail & & & \\
\hline
\end{tabular}

i. National Coordination Units include around 300 government officials (2010) that are responsible for following OECD topics. These officials are attached to different government organisations (i.e. municipalities, think tanks, associations, etc.). The Ministry of Economy has been assigned as one of the national coordination units for the OECD Trade Committee, OECD Investment Committee and OECD Steel Committee. The Ministry of Finance is the second National Coordination Unit in the two OECD committees. National Coordination Units are responsible for the coordination and reporting of the OECD studies followed by national government officials and communicating them to the OECD Secretariat. 
Network actors in National Coordination Units are the participants in the annual meetings of National Coordination Meetings related to OECD issues. These meetings are held twice a year, one in Ankara and one in Paris with the head of OECD Permanent Delegation. The main aim of National Coordination Meetings is to enhance bilateral relations with the OECD. National coordination meetings provide an opportunity for the OECD Delegation and national policy officials to exchange information about their study topics and good governance programmes for the nation, about emerging priorities, assessment of past actions, and the role of national institutions in this context.

ii. The OECD Turkish Permanent Delegation includes government official of Turkish ambassador and diplomats in OECD Delegation in Paris. They maintain a permanent delegation to the OECD with contributions according to the size of a states' economy and national government policy programmes. The OECD Delegation plays an important role in information exchange that provides connections between the OECD Secretariat and national authorities. The delegation represents national governments' positions during negotiations and helps to diffuse OECD policy recommendations to the relevant national government officials. Interaction before meeting participation between officials in the National Coordination Units and the OECD Turkish Permanent Delegation has been done mostly at the request of government officials by email, telephone and face to face conversations.

iii. OECD Committees provide professional interactions among representatives of the all OECD member states and have an objective of advancing ideas and reviewing progress in different policy areas. In 2012, there were about 250 committees, working groups and expert groups. OECD Committee Network actors invite senior officials (in 2012, around 40,000) from different state administrations in order to review and to contribute to the studies undertaken by the OECD Secretariat.

The internal web-portal provided by OECD Committee, called OLIS, was introduced at 2009. The main aim of this portal is to meet the information requirements of OECD Delegates (who need to know about OECD Committee work), policy officials (who need access to OECD Committee information related to their work on national issues) and government officials (who use OECD studies in their areas). Each authorized government official can open an OLIS account free of charge. Officials can use their OLIS account to interact with the OECD Secretariat during the preparation for OECD Committee meetings and to access information provided by an OECD Committee (e.g., work-in-progress reports, event details, official documents archive, publications and statistics) with secure internet access. In this respect, besides access to economic and social policy studies, using OLIS has a vital role for government officials, facilitating the review of OECD Committee works that are likely to impact their national policy work as well as influence the direction of Committee discussions through national delegates.

iv. The OECD Secretariat supports the committees and work in response to priorities decided by the OECD Council (the decision-making body of the OECD that consists of one representative from each member state and a representative of the European Commission). In 2012, the OECD Secretariat had around 2,500 actors with different expertise: economists, lawyers, scientists and other professionals.

An internal web-portal working as storage system for methodological information called "Clearspace" was introduced as an information sharing network by the OECD Secretariat at the 
beginning of 2010. This system had the objective of giving information to OECD Permanent Delegation and National Coordination Unit actors on methodological surveys launched by the OECD Secretariat. Clearspace brings transparency by opening the storage system to national government officials and international experts (mainly actors that are working on financial data collection) and allowing them to update, download request documents and comment on the information.

\subsection{Framework of Study}

In our study, we examined the direct interaction between actors from national institutions and the OECD Secretariat network by considering the questions related to the use of two web-portals: OLIS and Clearspace. Each OECD government official (regardless of which OECD topic that they are following) can open both an OLIS and Clearspace account free of charge and could use both of them for different reasons that create add value to the national policy work.

Figure 1 visualizes the framework of study using three concepts: influencer networks, information channels and governmental officials. Our study considers four main OECD work drivers that provide information in order to analyse the outcome behaviour of officials by use of OECD information and communication channels. To what extent do governments' supply side policy tools and organisational factors influence officials' outcome behaviour? Do certain attributes have an influence on the use of certain information channels? If yes, with which features could we explain the reasons for this? In the study, another important driver of the OECD Council is excluded from the analysis. The OECD Council is a strategic director who provides information to government officials indirectly by the output of OECD Ministerial Council Meetings.

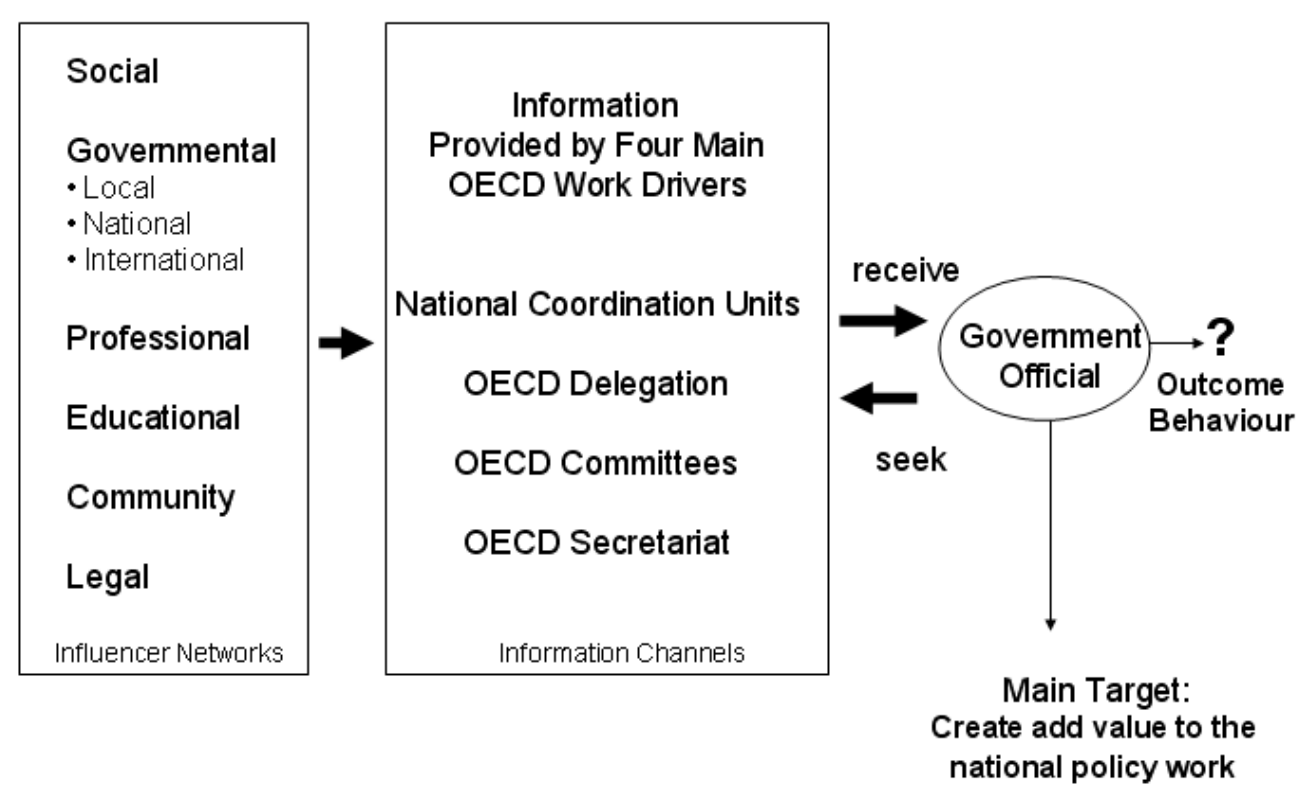

Figure 1. Framework of the study

Source: adapted from the concept of study of Boyd,A.,(2004) [5].

\section{DATA AND SUMMARY STATISTICS}

\subsection{OECD Topics followed by Turkish Government Officials}


Empirical data was collected using an online survey addressing 300 Turkish top-level country and municipal government officials working on OECD topics in 2010. 126 officials working on different topics returned usable questionnaires. 123 officials (out of 126) have answered to the questions of "Do you have OLIS account" and "'Do you have Clearpace account" that help to realize our innovation adoption models.

Figure 2 shows a visualization of the network generated by the 20 OECD study topics followed by Turkish government officials in 2010. These studies includes agriculture and fisheries, corruption, economy and finance, education, environment, industry and entrepreneurship, innovation, international migration, internet, investment, public government, regional development, science and technology, social and welfare issues, tax, trade, logistics, tourism, infrastructure, and energy.

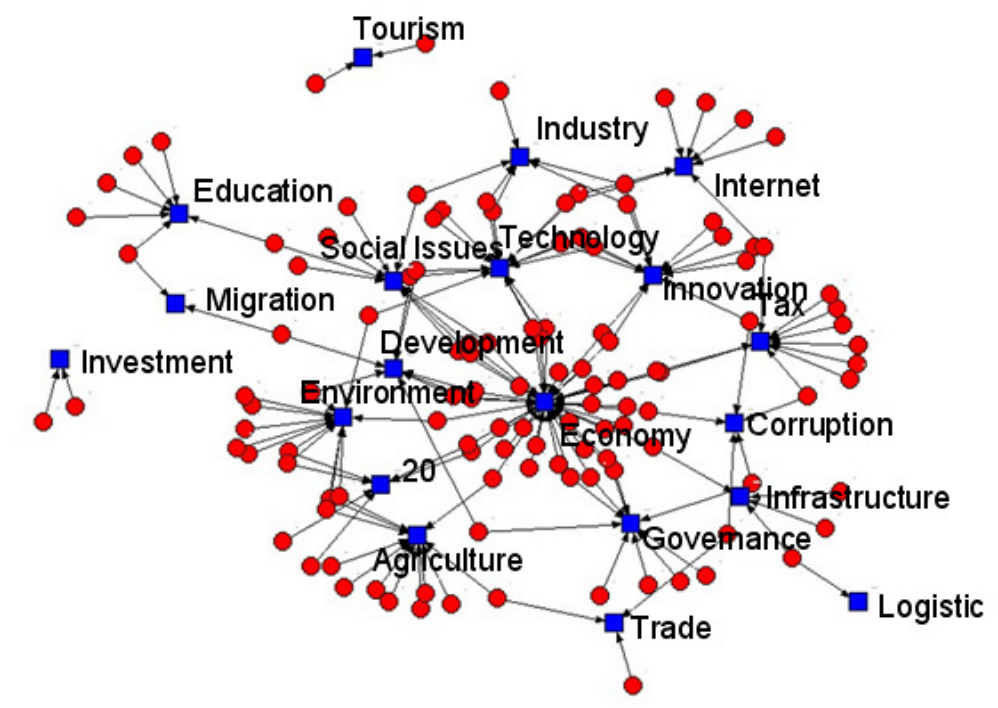

Figure 2. 20 OECD Topics Followed by Turkish Government Officials $(n=126)$ Source: OECD Survey of Turkish Government Officials, 2010.

In the Figure 2, UCINET software was used to visualise central connectivity in the network [6]. Blue squares show 20 OECD study topics, and red circles show surveyed government officials. This algorithm locates the nodes in the center of X-Y space by the number of connectedness. If one actor studies more than one topic, we this actor (red circle) is located equidistant from his/her study topics (blue squares). This figure illustrates that economic issues had a central role. However, the majority of officials working on topics related to economics also followed other research areas at the same time. OECD topics such as investment and tourism were being pursued by officials that were not working any other OECD topics.

\subsection{Adopters and Non-Adopters of Internal Web Technologies (IWT)}


We studied the OLIS and Clearspace web-portals as examples of IWT applications that were adopted by Turkish government officers. If a responder opened the tested web-portal account and used this portal application from their own account, we coded the response as 1 and called the responder an adopter, otherwise the variable was coded as 0 and the responder was called a non-adopter.

Table 1 indicates the distribution of adopters and non-adopters of OLIS and Clearspace with their e-mail alert services. This study does not consider the adoption of OLIS and CS alert services due to the high correlation between adoption of alert service accounts and the adoption of its main application. The OLIS application account was the most widely adopted, followed by the OLIS-Alert Service. Due to Clearspace application existing since the beginning of 2010, Clearspace accounts and the Clearspace e-mail alert system was adopted by few officials.

Table 2. Distribution of Adopters and Non-Adopters of OLIS and Clearspace web-portals

\begin{tabular}{|l|c|c|c|}
\hline Internal Web Technologies & \# of Non-Adopters & \# of Adopters & Total \\
\hline OLIS web-portal & $24(20 \%)$ & $99(80 \%)$ & 123 \\
\hline OLIS e-mail alert system & $67(56 \%)$ & $52(44 \%)$ & 119 \\
\hline Clearspace web-portal & $100(82 \%)$ & $22(18 \%)$ & 122 \\
\hline Clearspace e-mail alert system & $98(91 \%)$ & $10(9 \%)$ & 108 \\
\hline
\end{tabular}

Source: OECD Survey of Turkish Government Officials, 2010.

\subsection{Identification of Studied Influence Factors}

\section{Government Role in Innovation Adoption}

To test the role of government in the adoption of internal web technologies, this study considers supply side oriented policy tools. These are mainly variables related to the provision of intellectual infrastructure and a skilled workforce. To estimate the degree of provision the study used two factors: provision of experienced officials and provision of a specialized workforce for OECD topics.

The variable provision of experienced officials was measured as the government officials' duration working at the current institute and officials' duration of work on OECD study topics. The length of time working at the current institute and on OECD study topics was operationalized with the sum of the working years of officials. These two variables were measured on a 5-point scale, where 1 indicates one year and less, 2; two and three years, 3; four and five years, 4; six to eight years and 5; nine or more than nine years of working experience.

Provision of a specialized workforce by government was measured by the priority of following OECD study topics in the task descriptions of officers, each officer's level of expertise on his/her study topic, officials' frequency of OECD meeting participation and the number of OECD topics followed by officers. Although descriptions of tasks related to OECD work defined needs to fulfill, at some of the institutional units there were officials who followed OECD topics alongside their main task (as a non-primary task) as well as some who followed OECD studies that were not directly related to their area of expertise. The variables of priority and expertise were measured on a 5-point scale where 1 indicates a low and 5 indicates a high priority of 
International Journal of Managing Public Sector Information and Communication Technologies (IJMPICT) Vol. 5, No. 4, December 2014

OECD work in terms of officials' task descriptions and their level of expertise in the following OECD work. The third variable relates to provision of a specialized workforce on OECD projects, and was tested as the degree to which potential adopters participated in OECD meetings that were related to their study topics in Paris. Participation in these meetings was financed by the relevant institution's budget. Who would participate and how regularly was decided by the head department of the relevant institution. Regular participation in meetings could differ according to the specific management rules of the public institution. To measure the specialization (professionalization) of officials, this study used the sum of OECD meetings participated in by officials. Meeting participation frequency was measured on a 5-point scale where 1 indicates never and 5 indicates a total of ten and more than ten meetings attended by officials. Finally, the number of OECD topics followed by surveyed officers used as a degree of specialization (professionalization). Due to low number of officers in the responding organisation, in some institutions, officials needed to follow more than one OECD study topic.

In our model, to capture the differences between the adoption behaviour of officials a binary variable was used where 0 indicates one OECD study follower and 1 indicated more than one OECD study followers.

Role of Organisational Factors in Innovation Adoption

The influence of organisational characteristics on innovation adoption decisions functions through three factors that can be attributed to the officials as follows: previous adoption of intraorganisational web-portals, interpersonal communication and the perceptions of bureaucracy in the institution.

In the study previous adoption of intra-organisational web-portals was tested using the Clearspace adoption model. Analysis was based on the assumption that "having adopted intraorganisational web-portal at time $t$ is likely to lead to adoption of a recently launched web-portal at time $t+1$ ". We used respondents' behaviour of adopting an OLIS web-portal account as an explanatory variable. A dummy variable has used to indicate whether a responder has opened an OLIS account or not.

To measure the role of interpersonal communication in innovation adoption, two OECD Work Drivers (the National Coordination Units and the OECD Turkish Permanent Delegation) were studied in the investigation. To capture the use of information and communication channels by officials, this study focused on their interaction with two actors: (i) colleagues at national institutions that had previous experience on OECD studies, (ii) representatives that were specialists in study topic(s) from the OECD Delegation. Each interaction is constructed as a dummy variable where 0 indicates no interaction and 1 indicates interaction with actors from these two OECD Work Drivers.

An official's perceptions of bureaucracy in the institution are a measure based on two main questions: (i) perceived satisfaction with information provision (technical and timing issues) (ii) perceived effectiveness of the organisation's ability to use OECD studies (at both an institutional and actor level). Each question uses a 4-point scale where 1 indicates low satisfaction and/or effectiveness and 4 indicates high satisfaction and/or effectiveness with bureaucracy.

\section{ECONOMETRIC MODEL}


This study aims to estimate the factors influencing Turkish government officials' adoption of IWT using the examples of the adoption of two OECD web-portals. Since opening an account on these two OECD web-portals is not obligatory and depends on the choice of officials, we employed this choice problem as a way of analysing officials' innovation adoption behaviour. In the previous scholars, choice problems considered as a part of discrete decisions that are made by individuals towards the impact of future outcomes. In economics, choices over type of investment decisions are in part driven by the decisions that affect future earnings. Examples can be found in many study areas. Similarly, adoption decision has been widely used as a dichotomous problem in the public administrative literature $[7,8,9,10,11]$. Our study based on the studies of innovation adoption in public administration where the choice problem investigating by the discrete choice models such as logit or probit regression models.

The difference between a logit and probit model is the distribution function of the error term. Having applied both models, the choice of which to use in our analysis has derived by the results of models' (R-squared) explanatory power. Since the R-square is lower in the probit model, logit model is selected for analysis.

Turkish officials' innovation adoption behaviour modelled by the two logit regression models, which assign the probability of our dependent variable to be $1(\mathrm{Yi}=1)$. $\mathrm{Yi}=1$ is assigned to officials that have made an initial action to use the OECD information and communication channels of OLIS and Clear space web-portals.

In our model, the innovation adoption model is determined with two equations: the adoption of intra-organisational information and the application of the OLIS and Clearspace web-portals. In the first equation, opening an OLIS account was modelled as a function of the role of provision of an experienced (work_i and work_o) and specialized workforce (priority and topics), interpersonal communication (com_del and com_col), and official's perceptions of bureaucracy (effect_o, effect_m and timing). In the second equation, opening a Clear space account was modelled as a function of the same variables with the additional variable of previously having an OLIS account (olis). These two equations are specified as:

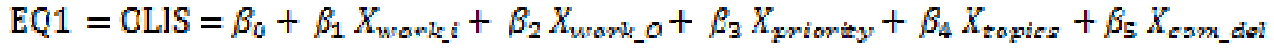

$$
\begin{aligned}
& +\beta_{6} X_{\text {ocm_al }}+\beta_{7} X_{\text {eff } \text { ect }_{-} O}+\beta_{8} X_{\text {ejf fect } m}+\beta_{9} X_{\text {timing }}+\varepsilon \\
& \mathrm{EQ} 2=\text { Clearspace }=\beta_{0}+\beta_{1} X_{\text {worki }}+\beta_{2} X_{\text {work }}+\beta_{3} X_{\text {priority }} \\
& +\beta_{4} X_{\text {topics }}+\beta_{5} X_{\text {olis }}+\beta_{6} X_{\text {com_del }}+\beta_{7} X_{\text {com_col }}+\beta_{8} X_{\text {effoct_o }}+9 X_{\text {effoct } m} \\
& +\beta_{10} X_{\text {timing }}+\varepsilon
\end{aligned}
$$

The potential problem of multicollinearity between explanatory variables was avoided by applying the pairwise correlation coefficient. Coefficient values of explanatory variables that were tested ranged from 0.011 to 0.546 . Based on the results of the correlation test, three variables "meeting participation", "expertise of officials" and "technical satisfaction with information provision" are not included in the models as a separate variable. Because these variables are highly correlated (larger than 0.4 ) with the variables of "duration of work on OECD study topics (work_o)", "priority of OECD projects in terms of official's tasks (priority)" and "satisfaction of officials with information provision (timing)" respectively. 
Studies used Menard's [12] approach and calculated the variance inflation factor (VIF) by constructing an ordinary least squares (OLS) regression with the given variables in both equations. The result shows a mean VIF value of 1.33 for both OLIS and Clearspace models. By accepting the upper critical limit of 10.0 [13], this study considers there to be no high correlation between the explanatory variables used in the OLIS and Clearspace models.

\section{FINDINGS}

\subsection{Use of OECD Information and Communication Channels}

To get an overview of the initial actions related to the use of OECD information and communication channels, this study mapped the officials as an individual actor in the information exchange network (Figure 4). The structure of the links was constructed via two main interactions: (i) voluntary pair-wise interactions; being aware of the key officer at the OECD Permanent Delegation (coded as Delegation) and communicating with other government officials before meeting participation (coded as Other Officals) (ii) interactions using IWT, such as use of OLIS and Clearspace web-portals.

In the visualization, the nodes that represent officials are shaped according to an actor's discrete choice. Actors that had no initial action, such as no OLIS and Clearspace account, were filtered out from the network. Of the whole sample, government officials who had a Clearspace account were around $20 \%$ and officials who had an OLIS account were around $80 \%$. From the resulting network, we observe that opening an OLIS account and knowing officials from the OECD Permanent Delegation seems to play an important role in the national work task of actors.

Another relevant interaction is that of exchanging information with other officials before meetings. As expected, because Clearspace was only introduced at the beginning of the survey year, there were only a few connected actors and the majority of these actors also had an OLIS account and knew officials from the OECD Permanent Delegation.

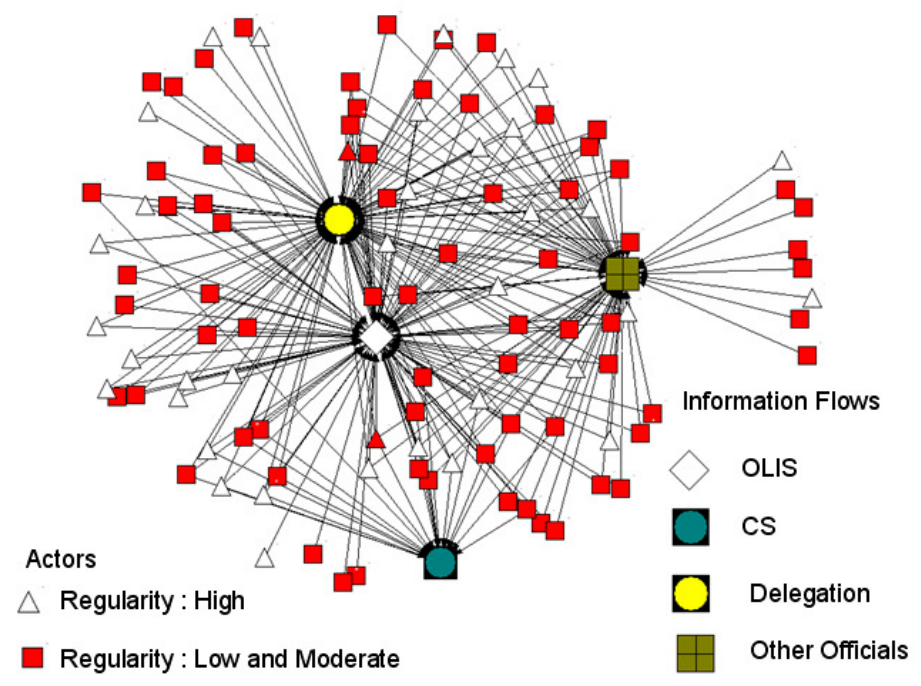

Figure 4. Network of Turkish Government Officials: use of OECD Information and Communication Channels

Source: OECD Survey of Turkish Government Officials, 2010. 
Note: UCINET software used to visualise central connectivity in the network [6]. This figure shows the results of initial action to use OECD information and communication channels among Turkish government officials, $n=115$. The regularity of officials' OECD meeting participation is classified into three groups of participants: officials who participated less than once a year (low), officials who participated at least once a year (moderate) and more than once a year (high).

\subsection{Influence of Three Factors on Use of OECD Information and Communication Channels}

The influence of the three defined factors (regularity, specialization and priority settings) on the officials' outcome behaviour of using information and communication was examined using probability tables (Table 3 ).

Table 3. Influence of Three Factors on Use of Information Channels: Probability Table with Marginal Frequencies (\%)

\begin{tabular}{|c|c|c|c|c|c|c|c|c|c|c|c|c|c|c|c|}
\hline & & \multicolumn{10}{|c|}{ Online } & \multicolumn{4}{|c|}{ Face to Face } \\
\hline & & \multicolumn{5}{|c|}{$\begin{array}{l}\text { Frequency of use of the OLIS web- } \\
\text { portal } \\
\text { (use olis) }\end{array}$} & \multicolumn{5}{|c|}{$\begin{array}{l}\text { Frequency of use of the } \\
\text { Clearspace web-portal } \\
\text { (use clearspace) }\end{array}$} & \multicolumn{2}{|c|}{$\begin{array}{l}\text { Communication } \\
\text { with OECD } \\
\text { Turkish } \\
\text { Delegation } \\
\text { (com del) }\end{array}$} & \multicolumn{2}{|c|}{$\begin{array}{l}\text { Communicatior } \\
\text { with other } \\
\text { government } \\
\text { officials } \\
\text { (com off) }\end{array}$} \\
\hline & & 1 & 2 & 3 & 4 & 5 & 1 & 2 & 3 & 4 & 5 & 0 & 1 & 0 & 1 \\
\hline Regularity & High & 14.6 & 24.3 & 29.2 & 26.8 & 4.8 & 77.7 & 5.5 & 11.1 & 2.7 & 2.7 & 15.3 & 84.6 & 42.8 & 57.1 \\
\hline \multirow[t]{2}{*}{ Specialization } & $=0$ & 15.6 & 31.3 & 31.3 & 19.6 & 1.9 & 73.3 & 11.1 & 8.8 & 4.4 & 2.2 & 22.2 & 77.7 & 29.0 & 70.9 \\
\hline & $=1$ & 7.9 & 33.3 & 36.5 & 20.6 & 1.5 & 75.4 & 13.2 & 7.5 & 3.7 & 0 & 23.3 & 76.6 & 46.7 & 53.2 \\
\hline Priority & $\begin{array}{l}=0 \\
=1\end{array}$ & $\begin{array}{l}11.1 \\
9.3\end{array}$ & $\begin{array}{l}36.1 \\
29.3\end{array}$ & $\begin{array}{l}38.8 \\
33.3\end{array}$ & $\begin{array}{l}11.1 \\
26.6\end{array}$ & $\begin{array}{l}2.7 \\
1.3\end{array}$ & $\begin{array}{l}81.2 \\
68.7\end{array}$ & $\begin{array}{l}3.1 \\
17.1\end{array}$ & $\begin{array}{l}9.3 \\
7.8\end{array}$ & $\begin{array}{l}6.2 \\
4.6\end{array}$ & $\begin{array}{l}0 \\
1.5\end{array}$ & $\begin{array}{l}30.7 \\
16.6\end{array}$ & $\begin{array}{l}69.2 \\
83.3\end{array}$ & $\begin{array}{l}30.7 \\
42.1\end{array}$ & $\begin{array}{l}69.2 \\
57.8\end{array}$ \\
\hline \multicolumn{16}{|c|}{$\begin{array}{l}\text { Description of the Three Factors: } \\
\text { Regula rity: Regulanity of officials'participation in OECD meetings. Low for officials who participate less than once a year; moderate for officials } \\
\text { who participate minimum once a year and high for officials who participate more than once a year. } \\
\text { Specialization: Degree of specialization of officials working on OECD topics. } 0=0 \text { fficials that follow only one OECD topic; } 1=0 \text { fficials who } \\
\text { follow more than one OECD topic. } \\
\text { Priority: The prionity of officials'tasks. } 0=0 \text { fficials that give a moderate prionity to OECD work; } 1=0 \text { fficials that give a high prionity to OECD } \\
\text { work. }\end{array}$} \\
\hline \multicolumn{16}{|c|}{$\begin{array}{l}\text { Description of Four Information Channels: } \\
\text { use olis: Usage frequency of OLIS account } 1= \\
\text { use clearspace: Usage frequency of CS accou } \\
\text { com del: Commurication with the OECD Turk }\end{array}$} \\
\hline
\end{tabular}

Regularity. In Table 3, the first three rows show the probability of officials' use of information channels by meeting participation regularity. Probability of use of OLIS and communication with a representative from the delegation are high for the officials that participate in OECD meetings regularly. However, the probability of using a Clearspace account is similar for the categories of low, moderate and high meeting participation. The probability of communication with other officials (before meeting participation) is lower for the officials that participate in meetings regularly relative to those who participate with low and moderate regularity. This implies that officials who are already participate regularly in meetings have a low probability of communicating with other national government officials.

Specialization. In Table 3, the specialization row reflects the probability of use of information and communication channels by the degree of specialization of officials on OECD topics. 0 
represents officials that were charged to follow more than one OECD topic, and 1 represents officials following only one OECD topic. We find that neither following more than one OECD topic nor following only one OECD topic resulted in significant probability differences on the frequency of use of the OLIS and Clearspace web-portals. This result is in line with the idea that officials who are required to follow more than one OECD topic would not show an outcome behaviour of more frequent use of information channels relative to officials who are required to follow only one OECD topic. Moreover, probability of communication with other officials is lower for the officials who specialized in OECD topics.

Priority. The last two rows of Table 3 give the probability of use of information and communication channels by the degree of priority. Priority 0 represents experts that pursued OECD with a moderate priority (in terms of their task description); priority 1 represents officials that gave OECD work a high priority. The findings show that there was a high probability of use of OLIS and communication with OECD Permanent Delegation actors among officials who gave OECD work a high priority relative to those who gave it a moderate priority. We conclude that probability of use of OLIS and communication with the representative from the delegation is higher for officials that gave a high priority to following OECD work.

\subsection{Logit Regression Estimation Results}

Table 4 shows the logit regression results for both equations: adoption of the OLIS and Clearspace web-portals. Tested predictors were treated as significant when the p-value was lower than 0.10. Results included the coefficients and significant levels of estimated explanatory variables. Logistic regression estimate results reveal how the government's supply side policy tools and organisational factors influence decisions to adopt IWT applications by Turkish OECD government officials.

Table 4. Logit Regression Results: Adoption of OLIS and Clearspace Accounts by Turkish Government Officials, $2010(\mathrm{~N}=123)$

\begin{tabular}{|l|c|c|}
\hline Explanatory Variables & $\begin{array}{c}\text { EQ1= } \\
\text { OLIS }\end{array}$ & $\begin{array}{c}\text { EQ2= } \\
\text { Clearspace }\end{array}$ \\
\hline Government Role (Supply Side Policy Tools) & & \\
\hline Provision of experienced officials & & \\
\hline Working at the current institute (years) & -0.172 & $-0.885^{* *}$ \\
\hline Working on OECD topics (years) & $0.735^{* *}$ & -0.261 \\
\hline Provision of a specialized workforce & & \\
\hline Priority of OECD work & -0.180 & $1.660^{*}$ \\
\hline Number of OECD Topics followed & 1.162 & 0.272 \\
\hline Organisational Factors (Characteristics of Adopters) & & \\
\hline Previous Adoption Behaviour & & \\
\hline Adoption of OLIS account & - & $1.185^{*}$ \\
\hline Interpersonal communication & & \\
\hline Communication with colleagues & -0.095 & 0.511 \\
\hline Communication with OECD Turkish Delegation & $1.370^{* *}$ & 0.520 \\
\hline Bureaucratization & & \\
\hline
\end{tabular}


International Journal of Managing Public Sector Information and Communication Technologies (IJMPICT) Vol. 5, No. 4, December 2014

\begin{tabular}{|l|c|c|}
\hline \multicolumn{1}{|c|}{ Effective use of OECD studies } & 0.219 & 0.270 \\
\hline Effectiveness of internal meetings & -0.422 & 0.310 \\
\hline Satisfaction with information provision (timing) & $0.720^{*}$ & $1.091^{*}$ \\
\hline Constant & 1.370 & -1.352 \\
\hline Number of Observations & 95 & 93 \\
\hline LR chi2(9) / LR chi2(10) & 15.37 & 21.67 \\
\hline Pseudo R2 & 0.166 & 0.253 \\
\hline Prob > chi2 & 0.081 & 0.016 \\
\hline
\end{tabular}

Source: OECD Survey of Turkish Government Officials, 2010.

Note: Significant levels: $*=p<0.10, * *=p<0.05$

\section{Government Role in Innovation Adoption}

Results support the hypothesis that a provision of experienced officials for the task of following OECD study topics increases the likelihood of adoption of web-portals as IWT. Other factors being equal, officials having higher levels of experience (years) at their institute was positively associated with the probability of opening an OLIS account, and officials having a higher level of experience at following OECD topics was positively associated with the probability of opening a Clearspace account.

The result for the variable "priority of OECD work" partly supports our hypothesis that provision of a specialized workforce influenced the probability of innovation adoption. While the priority of OECD work (in terms of the task description of officials) is not statistically significant in the OLIS model, there is a significant positive association to the probability of opening a Clearspace account. A positive coefficient sign reveals that the probability of having an Clearspace account increases with the increasing priority level of OECD study topics among officials' workload.

Following more than one OECD topic was found not to be a significant determinant for explaining adoption behaviour of web-portal applications for both models. However, one could expect that following several OECD topics needs a high effort on information sharing via intraorganisational applications. This indicates that following more than one OECD study topic does not necessarily facilitate adoption of the studied applications among officials.

\section{Role of Organisational Factors in Innovation Adoption}

These results confirm that previous adoption behaviour (here we used the opening of an OLIS account) has a positive influence on the opening of a Clearspace account. We have also conducted a t-test analysis where the differences of the means of two samples (adopters and nonadopters of Clearspace) were tested only for the previous adoption behaviour variable. The t-test analysis indicated that on average $95 \%$ of Clearspace adopters had an OLIS account.

The result for interpersonal communication partly supports our hypothesis that interpersonal communication has a positive influence on the probability of intra-organisational web-portal adoption. The positive sign for communication with the Delegation means that an increase in contact frequency with the responsible official of the OECD Turkish Delegation enhances the likelihood of opening an OLIS account. This could be explained by the results of information 
International Journal of Managing Public Sector Information and Communication Technologies (IJMPICT) Vol. 5, No. 4, December 2014

sharing between the OECD Delegation representative(s) and frequently contacted government officials. Information gathered from the Delegation representative allowed officers to have a greater understanding of the innovation (here the launched intra-organisational web-portal), and thereby reduce the official's uncertainty over the adoption decision.

The findings support the hypothesis that having a positive perception on bureaucratization is more likely to increase the chances of open a web-portal account. The perception of officials on the accessibility of technical reports on time is statistically significant and positively associated with the adoption probability of both tested web-portals.

\section{CONCLUSIONS AND DISCUSSION}

The particular focus of this paper is to analyze the use of OECD information and communication channels by Turkish government officials as a driver for the use of information and communication channels in an effective way. Our study contributes to the previous literature that highlights the importance of information technologies in politics [14] and bureaucracy [15] by giving insights on the adoption of information technologies in public sector among public officials within innovation diffusion concept [4].

The analysis aims to estimate the factors influencing the Turkish government officials' adoption of IWT using the adoption of two OECD web-portals. It has been argued that use of OECD information and communication channels has been influenced by the government's supply side policy tools and organisational factors.

As a first step three factors that were attributed to government officials were defined. These were regularity of officials' participation in OECD meetings, the degree of specialization on OECD topics and the degree of priority setting of following OECD work. The results show that while duration of employment and degree of expertise increase the probability of use of online information channels, work duration on OECD topics and meeting participation are the variables that decrease the probability of use of face to face communication channels. Additionally, officials involved in the group that worked only on one OECD topic do not have a higher probability of use of channels compared to officials in the group who worked on more than one OECD topic. However, officials from high regularity specialized and priority groups, who had a higher probability of using an OLIS account frequently and communicating with the OECD Turkish Permanent Delegation, had low probabilities of communicating with other national officials. Therefore, it is not surprising that most officials involved in OECD work favour more information exchange flows at a national level in order to tackle problems with the efficiency of the use of OECD studies. Officials that work on different OECD topics support the idea of increasing the efficiency of use of OECD studies by choosing only one government officer for OECD issues and maintaining regular meeting participation for that officer. This would increase the efficiency of national coordination and raise awareness of OECD studies at institute level. In the second step, with a logit regression model we estimated the influence of government's supply side policy tools and organisational factors on the adoption decision of open OLIS and Clearspace web-portal accounts. Overall, findings imply that the influence of the explanatory variables tested differ between the two models. Satisfaction with the timing of information provided by the OECD Permenant Delegation (timing issues in reaching reports) among officials is the only variable that consistently has a positive influence on the adoption of both web-portal applications. For the OLIS model, following OECD study topics (years), communication with 
those responsible for corresponding OECD study topics at the OECD Delegation and satisfaction with timing of access to technical reports are significant in explaining the adoption decision. In the Clearspace model, working at the current institute (years), priority of OECD work load in terms of officials' task description and satisfaction with the timing of information provision are found to be significant factors.

This study also shows the complexity of government officials' attributes (at institutional and national level) which presents many challenges for empirical research. From the theoretical perceptive, design of organisations has an influence on the use of information and communication channels. However, it is difficult to determine the optimal structure for efficient organisation and whether the information and communication channels are sufficiently used.

Communication literature that considers effectiveness highlights the needs within two-way approach: transmission and reception [16]. Fisher and Brown [16] state as "For communication to be effective, it needs to be two-ways: there must be not only transmission, but reception." The empirical data collected can only provide first indications in these regards. This completed survey shows the value of government officials' satisfactions with OECD information channels. Therefore, this analysis has considered the mental models of government officials by using their perceptions to the information provided by OECD drivers. Even though the data set on perceptions on effectiveness are subjective, our results confirm the certain evidence in line with self-evaluation of government officials.

\section{ACKNOWLEDGEMENTS}

The opportunity to explore the use of OECD information and communication channels arose from my traineeship at Permanent Delegation of Turkey to the OECD in 2010. I am thankful for efforts and support of OECD Turkish ambassador, Ahmet Kamil Erozan and all diplomats working Permanent Delegation of Turkey to the OECD in Paris for their support to realize this study. Yeliz H. Mursaloglu deserves special thanks for her collaboration during the data collection. Finally, I would like to thank to Dr. Doris Marquardt for her advices in the initial version of this study.

\section{REFERENCES}

1. Abbott, K. and Snidal, D, "Why States Act through Formal International Organizations", Journal of Conflict Resolution, vol 42, pp. 3-32, 1998.

2. Huber, W., New Approaches to Rural Policy: Lessons from around the world, Federal Coordination in Austria, in OECD(ed.), OECD, Paris, France, pp.61-65, 2005.

3. Brown, L., and Osborne, S. P., "Risk and innovation: Towards a framework for risk governance in public services”, Public Management Review, Vol.15, No. 2, pp.186-208, 2013.

4. Rogers, E.M., Diffusion of Innovations. New York: The Free Press, 2003.

5. Boyd A., "Multi-channel information seeking: a fuzzy conceptual model", Aslib Proceedings, Vol.56, Issue: 2, pp. $81-82004$.

6. Borgatti, S.P., Everett, M.G. and Freeman, L.C. Ucinet for Windows: Software for Social Network Analysis. Harvard, MA: Analytic Technologies, 2002.

7. Brudney, J., Selden, S., "The Adoption of Innovation by Smaller Local Governments: The Case of Computer Technology". American Review of Public Administration, Vol. 25, No.1, pp. 71-86, 1995.

8. Moon M.J., "The evolution of e-Government among Municipalities: rhetoric or reality?", Public Administration Review, Vol. 42, No 4, pp. 424-433, 2002. 
International Journal of Managing Public Sector Information and Communication Technologies (IJMPICT) Vol. 5, No. 4, December 2014

9. Ho, A.T. and K., Ni, "Explaining the Adoption of E-Government Features - a Case Study of Iowa County Treasurers", American Review of Public Administration Vol. 34, pp. 164-180, 2002.

10. Bhatti, Yosef, A.L. Olsen and L.H. Pedersen, "Administrative professionals and the diffusion of innovations”, Public Administration, Vol.89, No. 2, pp. 577-594, 2001.

11. Homburg V.M.F. and Dijkshoorn A.J.D., "Diffusion of personalized e-government services among Dutch municipalities, An Empirical Investigation and Explanation)", International Journal of E Government Research, Vol 7, No. 3, pp. 21-37 2011.

12. Menard, S., Applied Logistic Regression Analysis. 2nd ed. London: Sage, 2002.

13. Chatterjee, S. and Hadi, A.S., Regression Analysis by Example. 4th ed. Hoboken: John Wiley\& Sons, 2006.

14. Norris, P., "Who Surfs?: New Technology, Old Voters, and Virtual Democracy", In democracy.com, Governance in Networked Word, Elaine Ciulla Kamarck and Joseph S.,Nye, Jr. (eds.). NH: Hollis Publishing Company, 1999.

15. Fountain, J., "The Virtual State: Toward a Theory of Federal Bureaucracy", In democracy.com, Governance in Networked Word. Elaine Ciulla Kamarck and Joseph S. Nye, Jr. (eds.). NH: Hollis Publishing Company, 1999.

16. Fisher, R. and Brown, S., "Getting Together. Building relationships as we negotiate. New York: Penguin Books, 1998.

\section{Author}

İlkay UNAY GAILHARD holds master degrees on Economic Policy from Uludag University, Turkey in 2005 and Economics of Rural Development from the Montpellier SupAgro, France in 2008. She completed her traineeship on "Use of OECD information and communication channels" at Permanent Delegation of Turkey to the OECD, Paris. Having worked two years as a lecturer assistant at Department of Economics and Business in Northeast Normal University, China she is now working as a research associate and doing her PhD study at Leibniz Institute of Agricultural Development in Transition Economies (IAMO), Germany.

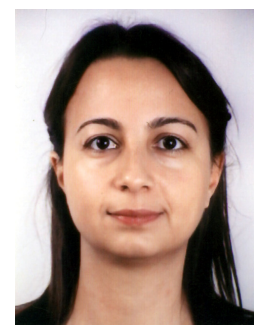

